\title{
Seasonal composition and activity of sulfate-reducing prokaryotic communities in seagrass bed sediments
}

\author{
April C. Smith ${ }^{1}$, Joel E. Kostka ${ }^{1, *}$, Richard Devereux ${ }^{2}$, Diane F. Yates ${ }^{2}$ \\ ${ }^{1}$ Department of Oceanography, Florida State University, Tallahassee, Florida 32306-4320, USA \\ ${ }^{2}$ US Environmental Protection Agency, National Health and Environmental Effects Research Laboratory, \\ Gulf Ecology Division, Gulf Breeze, Florida 32561, USA
}

\begin{abstract}
Sulfate-reducing prokaryotes (SRP) play a key role in the carbon and nutrient cycles of coastal marine, vegetated ecosystems; however, the interactions of SRP communities with aquatic plants remain little studied. The abundance, activity, and community composition of SRP were studied in relation to sediment geochemical gradients and plant growth state in a Thalassia testudinum seagrass bed and in adjacent unvegetated areas. Geochemical analyses indicated significantly higher concentrations of microbial respiration products in vegetated sediments during summer than during winter. Depth-integrated sulfate reduction rates were 3 to 5 times higher in vegetated (52.5 mmol m $\mathrm{m}^{-2} \mathrm{~d}^{-1}$ in summer and 20.4 to $26.5 \mathrm{mmol} \mathrm{m} \mathrm{m}^{-1}$ in winter) compared to unvegetated sediments (10.7 mmol m${ }^{-2} \mathrm{~d}^{-1}$ in summer and 3.6 to $7.6 \mathrm{mmol} \mathrm{m}^{-2} \mathrm{~d}^{-1}$ in winter), and depth-integrated activities further showed a strong correlation with seagrass biomass. Most probable number (MPN) counts of SRP were 10 times higher in vegetated compared to unvegetated sites in the summer during the period of maximum growth for seagrasses, whereas no difference was observed for counts between sites during the winter. The community composition of SRP was determined using restriction fragment length polymorphism (RFLP) screening and amino acid sequence comparisons inferred from partial dissimilatory bisulfite reductase ( $d s r A$ and $B$ ) genes that were PCR-amplified and cloned from DNA extracted from sediment samples. The majority of unique DSR sequences were not affiliated with any known SRP group, and clustered at levels indicative of new SRP. Some DSR sequences grouped on the basis of originating from vegetated or unvegetated sediments, although the relationship did not appear to be strong. The diversity of SRP in seagrass bed sediments, as indicated by $d s r$ analysis, was high and did not appear to covary with the other environmental parameters tested. Our results indicate that seagrass growth state enhances the abundance and activity of SRP, while SRP community composition remains relatively stable across the environmental parameters tested.
\end{abstract}

KEY WORDS: $d s r$ gene $\cdot$ Seagrass $\cdot$ Sulfate reduction $\cdot$ Sediment geochemistry $\cdot$ Sulfate-reducing bacteria

Resale or republication not permitted without written consent of the publisher

\section{INTRODUCTION}

Seagrass beds have high rates of primary productivity (Capone \& Taylor 1980, Holmer \& Bondgaard 1991, Duarte \& Chiscano 1999). They provide critical habitat for commercially important fish and shellfish, comprise a sensitive indicator of water quality, and act as a nutrient filter protecting the surrounding coastal zone from nutrient over-enrichment (Klumpp et al. 1989, Terrados \& Duarte 2000). Sulfate-reducing prokaryotes (SRP) have been established as key microorganisms catalyzing carbon and nutrient cycles in coastal marine sediments (Jørgensen 2000). Past studies have established a strong linkage between SRP and the ecology and geochemistry of the seagrass beds, particularly with regard to nitrogen fixation by SRP as a major source of plant nitrogen (Capone 1982, Waisel \& Agami 1996, Holmer \& Nielsen 1997, Holmer et al. 2001). However, the majority of evidence for the linkage between SRP and aquatic plants is geochemical and focuses on the activities of SRP. No microbiological studies have been carried out that explore the commu- 
nity composition of SRP in relation to their activity in seagrass sediments.

Seagrass bed sediments, as in other coastal marine ecosystems, become anoxic closely beneath the surface when oxygen is rapidly consumed by microorganisms. The need for a readily available terminal electron acceptor and the great abundance of sulfate in seawater then allows for the dominance of SRP in the mineralization of organic matter (Holmer \& Nielsen 1997, Jørgensen 2000). Geochemical evidence indicates that sulfate reduction is closely tied to carbon and nutrient cycles in seagrass bed sediments (Short 1987, Hansen et al. 2000, Holmer et al. 2001). SRP metabolism is thought to be fueled by carbon substrates supplied from root exudates in the seagrass rhizosphere (Holmer \& Nielsen 1997, Hines et al. 1999). In return, greater than $50 \%$ of the seagrass nitrogen requirement can be fulfilled with fixed nitrogen from SRP (Capone 1988, Nielsen et al. 2001). Nitrogen fixation occurs at higher rates within seagrass beds than in nearby unvegetated sediments (Welsh et al. 1996, Welsh 2000). Welsh et al. (1996) and Nielsen et al. (2001) estimated that SRP were responsible for mediating 60 to $95 \%$ of nitrogen fixation in the seagrass rhizosphere. Indeed, sequences for the functional gene of nitrogen fixation (nif $\mathrm{H}$ ) retrieved from seagrass bed sediments indicated that most sequences were from anaerobes affiliated with the SRP (Bagwell et al. 2002). In addition, a study by Holmer et al. (2001) showed that greater than $80 \%$ of the phosphate demand in seagrass bed sediments is regulated by organic matter turnover through sulfate reduction.

SRP community composition has been extensively studied in marine environments, including vegetated saltmarsh sediments, by $16 \mathrm{~S}$ rRNA gene sequence comparisons (Rooney-Varga et al. 1998, Edgcomb et al. 1999, Hines et al. 1999, Knoblauch et al. 1999, Li et al. 1999, Frischer et al. 2000, Ravenschlag et al. 2000, Joulian et al. 2001, King et al. 2001, Orphan et al. 2001, Pérez-Jiménez et al. 2001, Thomsen et al. 2001, LlobetBrossa et al. 2002). Molecular investigations of seagrass bed microbial communities have focused on $16 \mathrm{~S}$ rRNA gene sequences (Cifuentes et al. 2000) and nif $\mathrm{H}$ sequences (Bagwell et al. 2002). Phylogenetic groupings of SRP based on rRNA gene sequences are concurrent with the utilization of sulfate as a terminal electron acceptor (Devereux et al. 1989, Castro et al. 2000), and secondarily by an array of electron donors that would most likely provide resolution to the level of genera (Devereux et al. 1990, Devereux \& Stahl 1993). Adaptations required for living in vegetated sediments would be expected at the species or subspecies level and would require the use of a more variable sequence than 16S rRNA. The key functional gene for sulfate reduction, dissimilatory bisulfite reductase $(d s r)$, pro- vides better resolution for studying the genetic diversity of sulfate-reducers, as sought in this study. However, the majority of $d s r$ sequence comparisons to date have been primarily limited to the laboratory, microbial mats, or to cultures from marine sediments (Wagner et al. 1998, Joulian et al. 2001, Klein et al. 2001, Pérez-Jiménez et al. 2001). Fewer studies have extracted $d s r$ sequences directly from marine sediments (Thomsen et al. 2001, Dhillon et al. 2003, Liu et al. 2003), and one study used $d s r$ to examine SRP community composition between eutrophic and pristine freshwater wetland sediments (Castro et al. 2002), but the relation between SRP and dominant grasses through the use of $d s r$ has not yet been explored. Further, few studies have coupled a detailed DSR phylogeny with an extensive study of sulfate reduction activity and geochemical parameters.

The main objective of this study was to characterize the community composition and activities of SRP in relation to the growth state of seagrasses and sediment geochemistry. We hypothesized that seagrass physiology would enhance the abundance and activity of SRP, but would have less effect on the community composition of SRP due to the abundance of organic matter/ carbon substrates in both vegetated and unvegetated sediments. Analysis of DSR sequences from seagrass bed sediments confirmed the hypothesis. Our results indicated that there was a tight coupling between the activity/abundance of SRP and the growth state of seagrasses, but relatively few clusters of the clone sequences demonstrated an association with the presence or absence of seagrasses.

\section{MATERIALS AND METHODS}

Site characteristics and ecological parameters. This study was conducted in Santa Rosa Sound, part of the Pensacola Bay system in NW Florida, adjacent to the Naval Live Oaks Reservation (30 21.701' N, $\left.87^{\circ} 08.066^{\prime} \mathrm{W}\right)$. The site contained a large seagrass meadow dominated by Thalassia testudinum with some Halodule wrightii in sandy sediments. A vegetated station and an unvegetated station were sampled in February 2001, July 2001, and February 2002. Average water depth over the complete tidal cycle averaged $0.6 \mathrm{~m}$ with an approximate tidal range of $1.5 \mathrm{~m}$. Water temperatures ranged from highs of 25 to $30^{\circ} \mathrm{C}$ in the summer, to lows of 5 to $10^{\circ} \mathrm{C}$ in winter months. Salinity remained relatively constant in Santa Rosa Sound during the study, with a range of 25 to $30 \mathrm{ppt}$ (US Environmental Protection Agency, Gulf Ecology Division).

Seagrass height and density were measured at each sampling date. Above- and below-ground biomass 
were determined by collecting large cores $(8 \mathrm{~cm}$ inner diameter [i.d.]) in vegetated and unvegetated areas (control). Seagrass blade length was determined as the distance from the sediment surface to the tip of each shoot. Shoot density was determined by counting the number of shoots in each large core. Shoots were severed from the core at the sediment surface, rinsed with deionized water, and dried to a constant weight at $60^{\circ} \mathrm{C}$. Ash weights were obtained to determine the percentage of organic carbon by measuring loss-onignition at $550^{\circ} \mathrm{C}$ after $6 \mathrm{~h}$. Below-ground biomass was sieved to removed excess sediment from the core. The root/rhizome material was treated as described above for shoots to obtain the percentage of organic carbon.

Sediment handling and porewater extraction. Sediments for geochemical analyses were collected with polycarbonate core liners (6 $\mathrm{cm}$ i.d., $15 \mathrm{~cm}$ deep) and immediately sealed with butyl rubber stoppers. Triplicate cores were obtained from each site, with the exception of cores taken for porosity and density, which were taken in duplicate. Only cores where the surface appeared undisturbed at the time of collection were used.

Cores taken during the February 2001 sampling were sectioned into $1 \mathrm{~cm}$ intervals over $10 \mathrm{~cm}$. Cores from July 2001 were sectioned into seven 1 to $2 \mathrm{~cm}$ intervals over the top $10 \mathrm{~cm}$ depth $(0-1,1-2,2-3,3-4$, $4-6,6-8,8-10 \mathrm{~cm})$. All sediment intervals were transferred to a nitrogen-filled glove bag within $1 \mathrm{~h}$ of sampling. Sediments were loaded into $15 \mathrm{ml}$ tubes with holes punched in the bottom and covered by a $0.2 \mu \mathrm{m}$ GF/F filter, then placed within polypropylene centrifuge bottles and tightly capped. The sealed bottles were taken from the glove bag and centrifuged for 10 to $30 \mathrm{~min}$ at $5000 \times \mathrm{g}$ at room temperature to obtain porewater. The bottles were then transferred either back into the nitrogen-filled glove bag or into an anaerobic chamber. The porewaters were withdrawn from the bottles and filtered through $0.2 \mu \mathrm{m}$ celluloseacetate syringe filters into pre-labeled sample vials. Sediments from which the porewaters were collected were frozen for solid phase chemical analyses.

Geochemistry. Porewaters for $\mathrm{CO}_{2}$ and $\mathrm{NH}_{4}{ }^{+}$were filtered into $1.8 \mathrm{ml}$ glass vials and sealed with gastight, Teflon-coated butyl rubber septa with no remaining headspace in the vials to prevent degassing. Samples were stored at $4^{\circ} \mathrm{C}$ until analyzed by flow injection with conductivity detection (Hall \& Aller 1992), including the addition of mercuric chloride $\left(\mathrm{HgCl}_{2}\right)$ to reduce possible interference from hydrogen sulfide (Lustwerk \& Burdige 1995).

Porewaters for the remaining chemical analyses were filtered and collected in $2 \mathrm{ml}$ polypropylene screw-cap vials and frozen at $-20^{\circ} \mathrm{C}$ until analyzed. Nitrate was analyzed by chemiluminescence detection
(Braman \& Hendrix 1989). Sulfate concentrations were measured in acidified porewater using ion chromatography. Sediment $\mathrm{pH}$ was determined with a glass electrode, calibrated with NBS standards, that was inserted either directly into sediment cores or into filtered porewater.

Rate measurements. Sulfate reduction rates (SRR) were determined in triplicate on intact $10 \mathrm{~cm}$ long cores $(2 \mathrm{~cm}$ i.d.) within a few hours of sampling (Jørgensen 1978). Cores were maintained and equilibrated in an incubator at the in situ temperature prior to injection. ${ }^{35} \mathrm{SO}_{4}{ }^{2-}$ was injected at $1 \mathrm{~cm}$ intervals and cores were incubated at the in situ temperature for $4 \mathrm{~h}$. The cores were fractionated into 1 to $2 \mathrm{~cm}$ intervals, fixed in $10 \mathrm{ml} 20 \% \mathrm{ZnAc}$, and frozen. Reduced ${ }^{35} \mathrm{~S}$ was recovered by distillation with boiling acidic $\mathrm{Cr}^{2+}$ solution according to Fossing \& Jørgensen (1989).

Abundance of SRP. Densities of cultivatable SRP were enumerated using most probable number (MPN) assays. Ten-fold serial dilutions of sediment were made in a minimal salt water medium prepared according to Widdel \& Bak (1992). The medium contained both acetate and lactate as carbon substrates at a final concentration of $10 \mathrm{mM}$ each. Sulfate was the sole electron acceptor, and sulfide was added as a reductant. Tubes were incubated at $30^{\circ} \mathrm{C}$ in the dark and analyzed at 1 and 3 mo intervals. Sulfate reduction was scored by measuring the respiration product, dissolved sulfide (Cord-Ruwsich 1985), in comparison to autoclaved controls and no carbon controls. The MPN index was determined from statistical tables published by the American Public Health Association (1969).

Molecular characterization of SRP communities. Eleven sediment sections used for DNA extractions were frozen at $-80^{\circ} \mathrm{C}$ until ready for processing (3 depths, 2 sites, 2 seasons). The 0 to $2 \mathrm{~cm}$ depth interval from the unvegetated site in February 2001 was lost during centrifugation in the extraction procedure, leaving a total of 11 samples for processing.

Root material was removed and sediments from both sites were weighed prior to extractions. DNA was extracted from sediment using MoBio UltraClean ${ }^{\mathrm{TM}}$ Soil DNA kits. A $1.9 \mathrm{~kb} d s r A B$ gene fragment was amplified by PCR from DNA extracts with the primers DSR1F and DSR4R (Wagner et al. 1998). PCR mixtures of $25 \mu \mathrm{l}$ contained $0.3 \mu \mathrm{M}$ of each primer, 1 unit of Takara LA Taq, $2.5 \mu \mathrm{l} 10 \mathrm{LA}$ PCR buffer with $25 \mathrm{mM}$ $\mathrm{Mg}^{2+}$, and $2.5 \mathrm{mM}$ dNTP Mix (Takara Biomedicals). Twenty ng of DNA template was added prior to the beginning of the cycle. PCR amplification was performed in a GeneAmp PCR system 9700 (Applied Biosystems) with the following conditions: initial DNA denaturation of 2 min at $92^{\circ} \mathrm{C}$, followed by 30 cycles of $1 \mathrm{~min}$ at $92^{\circ} \mathrm{C}, 1 \mathrm{~min}$ at $48^{\circ} \mathrm{C}, 1 \mathrm{~min}$ at $72^{\circ} \mathrm{C}$, and then a final extension for $10 \mathrm{~min}$ at $72^{\circ} \mathrm{C}$. PCR products were 
electrophoresed on a $1 \%$ agarose gel in $1 \times$ TBE buffer to confirm the expected $1.9 \mathrm{~kb}$ size.

Cloning and sequencing. PCR products were cut from gels and cleaned using the QIAquick Gel Extraction Kit (QIAGEN). The products were then cloned into the pCR 2.1-Topo vector (Invitrogen Life Technologies), and transformed into Top 10 Escherichia coli competent cells (Invitrogen). In total, $50 \mu \mathrm{l}$ from each transformation reaction were spread onto each of 5 Luria-Bertani agar plates with kanamycin $\left(50 \mathrm{\mu g} \mathrm{ml}^{-1}\right)$ and X-gal $\left(40 \mathrm{mg} \mathrm{ml}^{-1}\right)$, and incubated at $37^{\circ} \mathrm{C}$ for $24 \mathrm{~h}$.

Fifty to 75 transformants from each of the 11 libraries were picked and transferred to new LB agar plates with kanamycin. Plasmid inserts were screened for the correct size by PCR directly from individual colonies with the M13F and M13R primers. $1.9 \mathrm{~kb} d s r A B$ PCR products were obtained from DNA extracts of vegetated and unvegetated sediments.

Plasmid DNA containing inserts of the correct size were digested with Hae III and the digests run on $3 \%$ agarose gels to identify unique clones. Selected clones were suspended in $10 \mu \mathrm{l}$ Tris ( $\mathrm{pH}=7.0$ ) buffer and preserved on a 96-well format CloneSaver FTA card (Whatman). CloneSaver punches were used in PCR reactions to obtain a clean template for sequencing. Sequencing was performed by the DNA Sequencing Facility, Florida State University, using the M13F and M13R primers. Cloned DNA sequences were converted to amino acid sequences and were initially identified through the use of BLAST. Partial $\alpha$ (177 amino acids) and partial $\beta$ (181 amino acids) $d s r$ subunit sequences were obtained for each clone. High diversity among clone sequences made it impossible to design a primer, or even several primers, to sequence between the $\alpha$ and $\beta$ subunits for all of these environmental clones.

A total of 378 positive clones were analyzed by RFLP (restriction fragment length polymorphism). RFLP analysis identified 222 unique groups in vegetated and unvegetated clone libraries, indicating diverse SRP communities. A total of 131 unique phylotypes originated from the vegetated site, while the remaining 91 phylotypes were from the unvegetated site. Analytical rarefaction of RFLP patterns confirmed high SRP community diversity, as only 3 curves from a total of 11 samples approached the expected plateau indicative of a community well-represented in a clone library.

Clone sequence ends were trimmed in SEQUENCHER (v. 3.1.1) and alignments for both the $\alpha$ and $\beta$ DSR subunits were obtained using Genetic Data Environment (v. 2.2), the Lasergene software package (DNASTAR), and BioEdit Sequence Alignment Editor (T. Hall, Dept. of Microbiology, North Carolina State University, Raleigh, NC). Sequences from known SRP genera were aligned with 63 clone sequences to form the SRP $\alpha$ subunit tree (see Fig. 4), and 69 clone sequences to build the SRP $\beta$ subunit tree (see Fig. 5). Phylogenetic trees were developed by parsimony analysis using PAUP (v. 4.0b10; D. L. Swofford, Sinauer Associates, Sunderland, MA). Bootstrapping analyses were performed with 100 resamplings of the amino acid sequences. Protein distances were estimated with PROTDIST.

Clone libraries were analyzed by rarefaction using aRarefactWin software (v. 1.3; S. Holland, Stratigraphy Lab, University of Georgia, Athens; www.uga.edu/ $\sim$ strata/software/).

Nucleotide sequence accession numbers. GenBank accession numbers for the partial $d s r$ gene sequences are AY266478 to AY266609.

Statistics. Statistical analyses were performed using Minitab (Release 14.1). Variations in geochemistry, as well as SRR were analyzed by 3-way ANOVA (depth, site, season) using a general linear model. Depthintegrated SRR were analyzed by 2-way ANOVA (site, season). When ANOVA p-values indicated significant differences between groups (based on a $p=0.05$ significance value), Tukey post-hoc tests were run to analyze all multiple pairwise comparisons. Correlations between depth-integrated SRR and seagrass biomass values were analyzed by Pearson's product moment correlation.

\section{RESULTS}

\section{Ecological parameters}

Total seagrass biomass, based on organic carbon content as determined by loss on ignition, was constant between seasons. However, significant differences in above- and below-ground biomass were detected with the change in season. Average above-ground biomass $\left(323.4 \pm 113.9 \mathrm{~g} \mathrm{C} \mathrm{m}^{-2}\right)$ was $38 \%$ of the total biomass during the summer, but only $4 \%$ of the total (35.12 \pm $\left.1.150 \mathrm{~g} \mathrm{C} \mathrm{m}^{-2}\right)$ during the winter $(\mathrm{p}=0.012)$. Belowground biomass showed the opposite trend, measuring $62 \%$ of the total biomass in the summer (533.47 \pm $111.2 \mathrm{~g} \mathrm{C} \mathrm{m}^{-2}$ ) and $96 \%$ of the total biomass in the winter $\left(884.03 \pm 42.65 \mathrm{~g} \mathrm{C} \mathrm{m}^{-2} ; \mathrm{p}=0.007\right)$.

\section{Geochemistry}

Porewater nitrate concentrations did not show consistent trends with depth or site, but did show a marked increase in summer over winter concentrations $(\mathrm{p}<$ 0.001) (Fig. 1a). Sulfate depletion was observed at depth in porewaters of unvegetated cores during summer, while porewater sulfate concentrations were con- 
February 2001

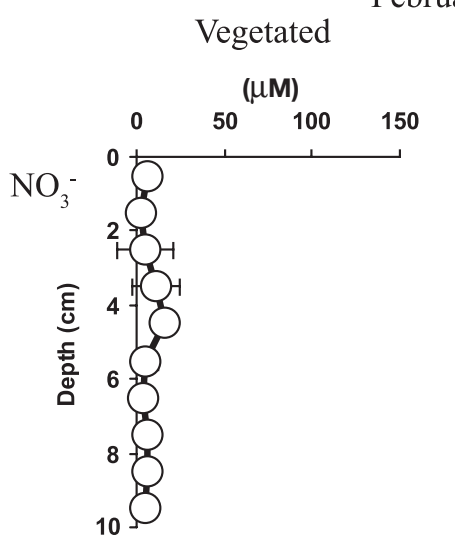

(m M)
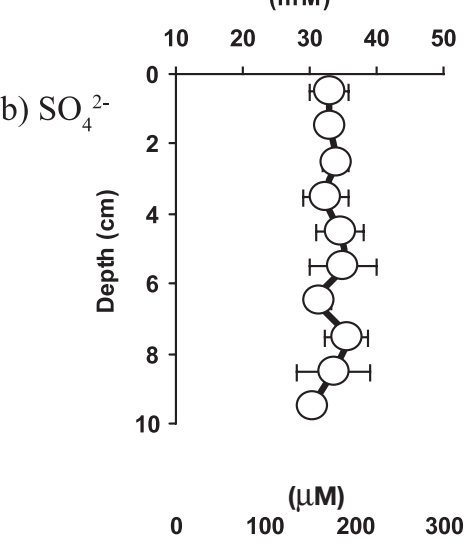

c) $\mathrm{NH}_{4}^{+}$

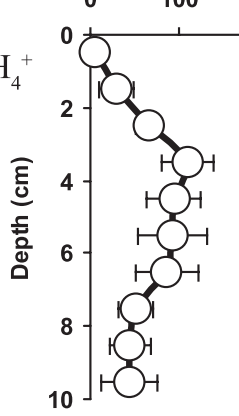

Unvegetated
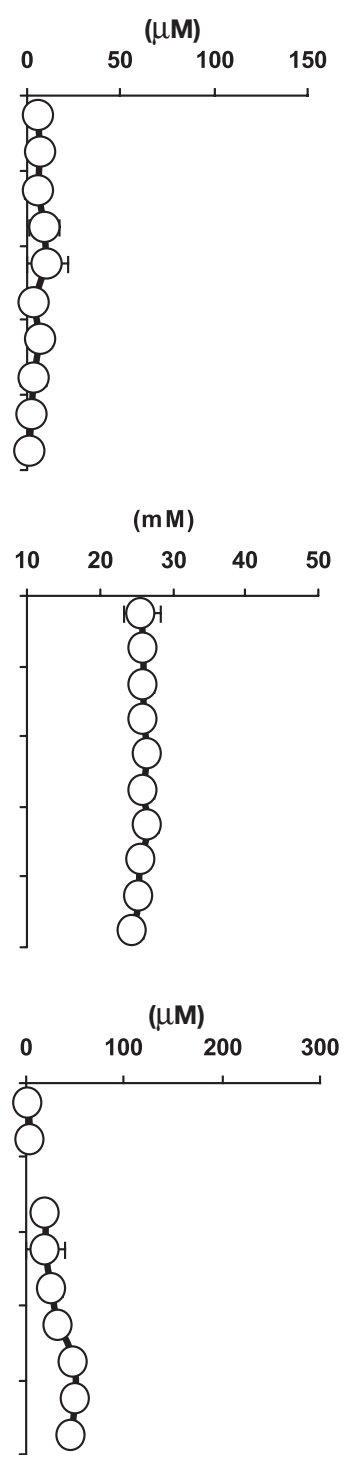

July 2001

Vegetated

Unvegetated
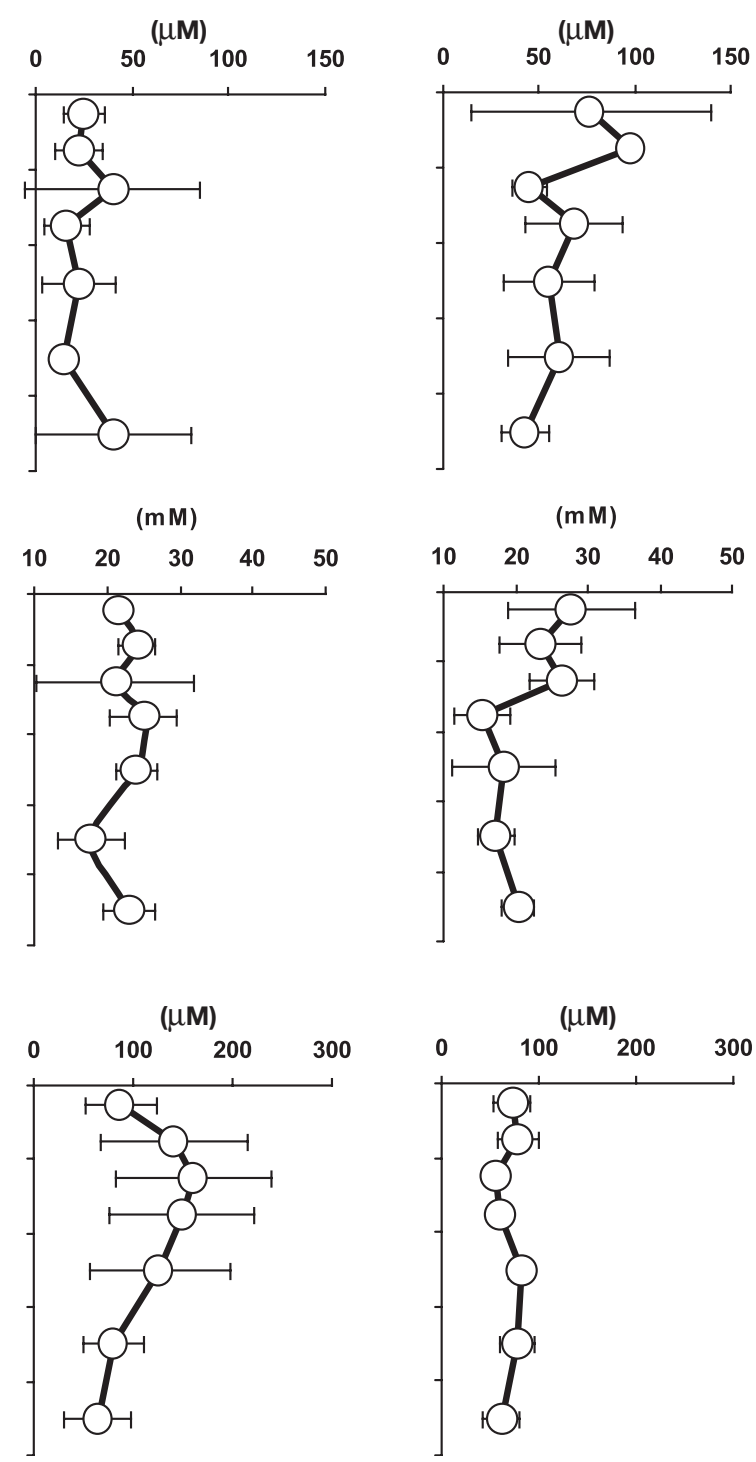

Fig. 1. Concentrations of porewater constituents (mean $\pm \mathrm{SD}$ ) measured in a seagrass bed and adjacent unvegetated sediments during summer and winter seasons

stant over depth in the remaining cores. Summer sulfate concentrations were significantly lower than winter concentrations $(p<0.001)$ (Fig. 1b), most likely due to higher sulfate reduction rates (SRR) during summer months. Vegetated sediments displayed higher sulfate concentrations than unvegetated sediments $(\mathrm{p}=$ 0.003), indicating faster recycling of sulfate due to the presence of seagrasses. DIC concentrations in porewaters were approximately $2 \mathrm{mM}$, increasing slightly with depth, but profiles did not change seasonally (data not shown). Porewater $\mathrm{NH}_{4}{ }^{+}$concentrations were higher during the summer sampling $(p<0.001)$ (Fig. 1c). Vegetated sediments contained significantly higher $\mathrm{NH}_{4}{ }^{+}$ concentrations than unvegetated sediments during all sampling periods $(\mathrm{p}<0.001)$. A subsurface $\mathrm{NH}_{4}{ }^{+}$maximum was present at 4 to $6 \mathrm{~cm}$ depth in vegetated sediments during all sampling periods, indicating enhanced remineralization in the root zone. Unvegetated sediments showed an accumulation at depth typical of subtidal profiles. During summer, the unvegetated site exhibited elevated $\mathrm{NH}_{4}{ }^{+}$concentrations relative to winter, indicative of faster remineralization rates.

\section{SRP activity}

The highest SRR were measured over the top 3 to $5 \mathrm{~cm}$ depth (p 0.007) (Fig. 2), in vegetated sediments 


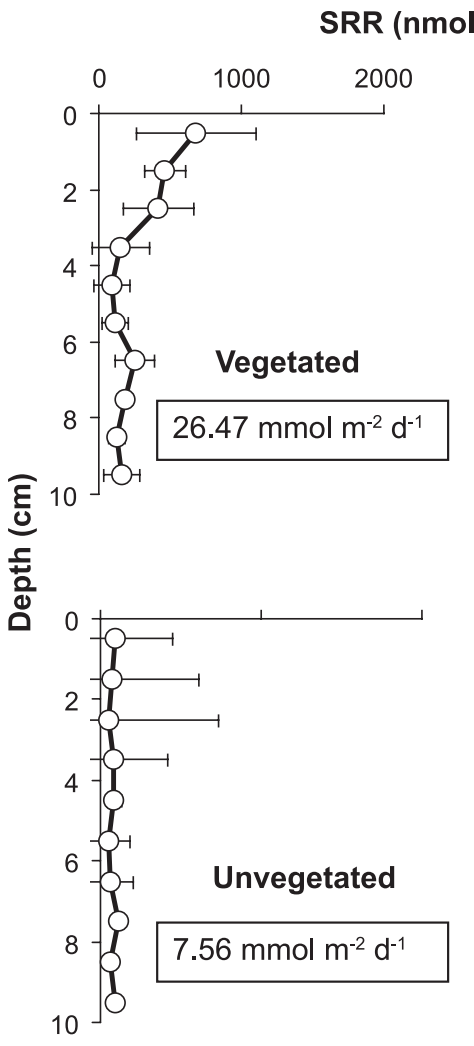

February 2001
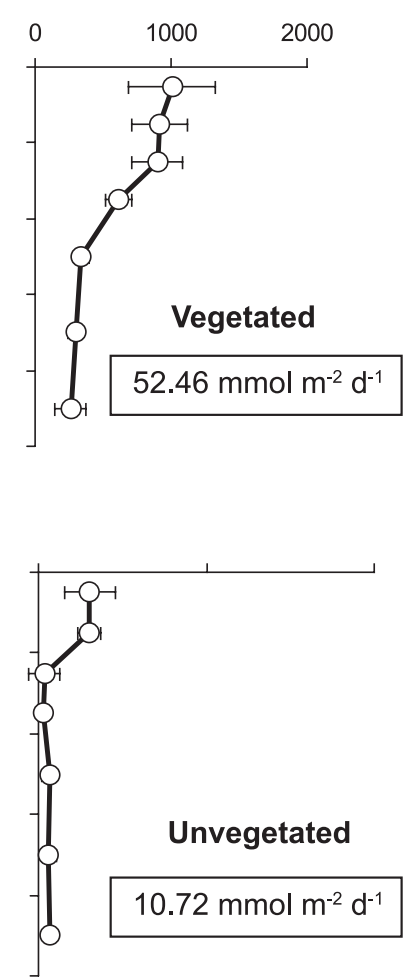

July 2001
Fig. 2. Sulfate reduction rates $\left(\mathrm{SRR}_{i}\right.$ mean $\left.\pm \mathrm{SD}\right)$ measured at the vegetated and unvegetated sites during winter and summer 2001. Values in boxes are depth-integrated SRR

during summer. Depth-integrated rates were approximately 2 times higher during the summer growth season in comparison to the winter season $(p<0.001)$ (Fig. 2) when seagrasses are less photosynthetically active (see above-ground biomass results above). The effect of plants on depth-integrated SRR was greater when comparing sediments vegetated by seagrasses to adjacent unvegetated sediments ( $\mathrm{p}<0.001)$ (Fig. 2). Depth-integrated SRR were 3 to 5 times higher in vegetated sediments $\left(52.46 \mathrm{mmol} \mathrm{m}^{-2} \mathrm{~d}^{-1}\right.$ in summer and 20.45 to $26.47 \mathrm{mmol} \mathrm{m}^{-2} \mathrm{~d}^{-1}$ in winter) than in unvegetated sediments (10.72 $\mathrm{mmol} \mathrm{m}^{-2} \mathrm{~d}^{-1}$ in summer and 3.64 to 7.56 mmol m $\mathrm{m}^{-2} \mathrm{~d}^{-1}$ in winter; $\mathrm{p}=0.001$ ).

Plots of depth-integrated SRR versus aboveand below-ground biomass (Fig. 3) indicated a significant correlation between SRP activity and the seagrass active growth phase. Pearson correlation coefficients (r) were positive and highly significant for the relationship between above-ground biomass and SRR $(\mathrm{r}=0.971 ; \mathrm{p}=$ 0.001; $\left.R^{2}=0.8936\right)$. The relationship between below-ground biomass and SRR was negative, yet also highly significant $\left(r=-0.957 ; p=0.003 ; R^{2}=0.9521\right)$, indicating an inverse relationship between these factors.

\section{SRP abundance}

The impact of seagrasses on SRP was corroborated with the results from determinations of SRP abundance using the MPN assay. MPN counts of viable SRP were an order of magnitude higher in vegetated ( 7 to $9 \times 10^{7}$ cells $\mathrm{ml}^{-1}$ ) than in unvegetated sediments (2 to $9 \times 10^{6}$ cells ml${ }^{-1}$ ), except for the 8 to $10 \mathrm{~cm}$ depths in winter (vegetated, $4 \times 10^{5}$ cells ml ${ }^{-1}$; unvegetated, $2 \times$ $10^{7}$ cells $\mathrm{ml}^{-1}$ ). There was no difference observed in SRP abundance between the sediment surface $(0$ to $2 \mathrm{~cm} ; 9 \times 10^{7}$ cells ml ${ }^{-1}$ ) and sediment depth (8 to $10 \mathrm{~cm}$; 2 to $9 \times 10^{6}$ cells $\mathrm{ml}^{-1}$ ) during the summer sampling at vegetated or unvegetated sites.

\section{Phylogenetic analysis of DSR sequences}

$\alpha$ and $\beta$ subunit phylogenies were congruent in several respects. Of the sequences obtained from the Naval Live Oaks sampling stations (Figs. 4 \& 5), $75 \%$ did not show close affiliation with any known SRP group, even at the family level. The two trees also include common sequence clusters within the branch representing the Desulfobulbaceae family (Cluster L; Figs. 4 \& 5), and clone sequences that grouped with sequences from Gram-positive SRP capable of completely oxidizing acetate to $\mathrm{CO}_{2}$ represented in the tree by Desulfotomaculum acetoxidans (61 to $85 \%$; Cluster J; Figs. 4 \& 5).

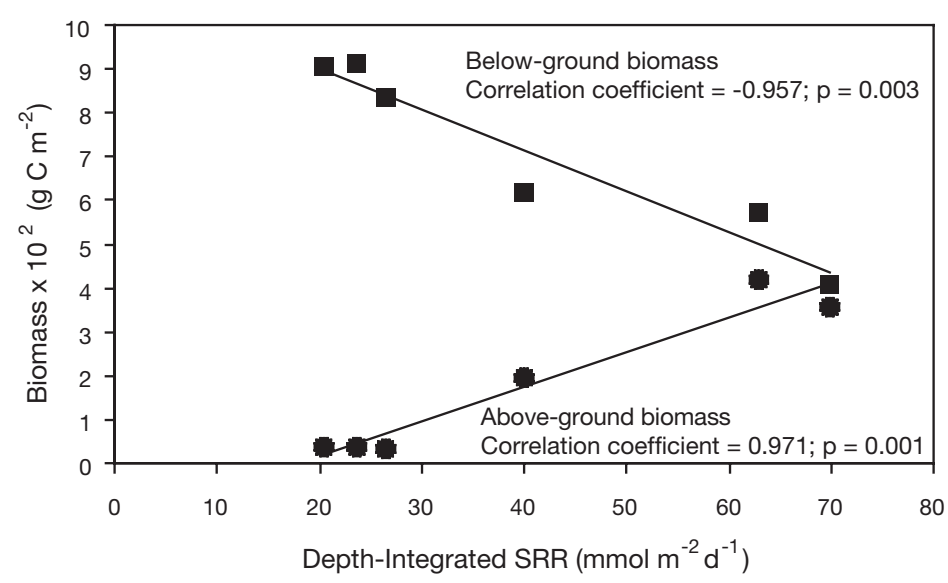

Fig. 3. Pearson product-moment correlation of sulfate reduction rates (SRR) versus seagrass biomass 
The $2 \alpha$-subunit Cluster A clones, VWC42 and USB72 (Fig. 4), were clearly affiliated with genera of the Desulfobacteriaceae, but $\beta$-subunits of the same clones were not affiliated with any known group. These 2 phylotypes were $\sim 94$ and 90\% similar to Desulfosarcina variabilis in the $\alpha$-subunit tree.
The $\alpha$-subunit tree also contained 1 sequence that clustered with Desulfosporosinus orientis (80\%; Cluster O; Fig. 4), a Gram-positive SRP that oxidizes lactate only to acetate. However, the $\beta$-subunit tree shows this clone sequence and 2 others to be extremely deepbranching bacteria, not previously identified with any

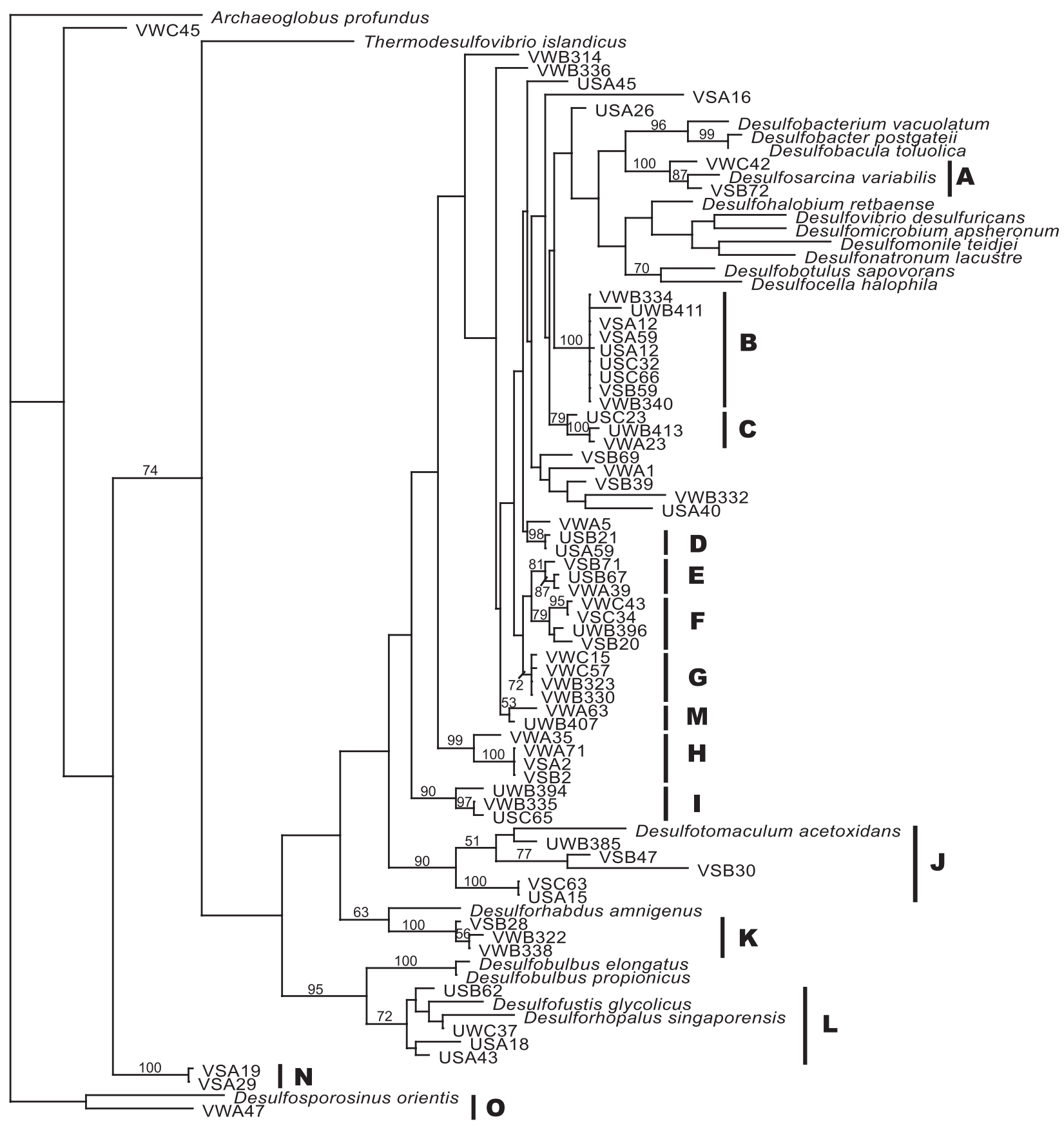
10

Fig. 4. Parsimony tree of $d s r \alpha$-subunit sequences. Clone sequences are designated according to site (vegetated [V] or unvegetated [U]), season (winter [W] or summer [S]), and depth (0 to $2 \mathrm{~cm}[\mathrm{~A}], 4$ to $6 \mathrm{~cm}[\mathrm{~B}], 8$ to $10 \mathrm{~cm}[\mathrm{C}])$ of collection. Scale bar represents 10 amino acid changes per 100 sequence positions. Capital letters in bold indicate clusters of clone sequences and reference organisms with bootstrap values $>70$ in at least 1 of 2 trees 
known group of SRP, and most closely related to Archaeoglobus profundus with $60 \%$ similarity.

Results of the sequence comparisons suggested that certain groups of SRP were preferentially found in either vegetated or unvegetated sediments. All of the clone sequences that clustered with the proposed Desulfobulbaceae family (Cluster L; Figs. 4 \& 5) were obtained from the unvegetated site. Although the

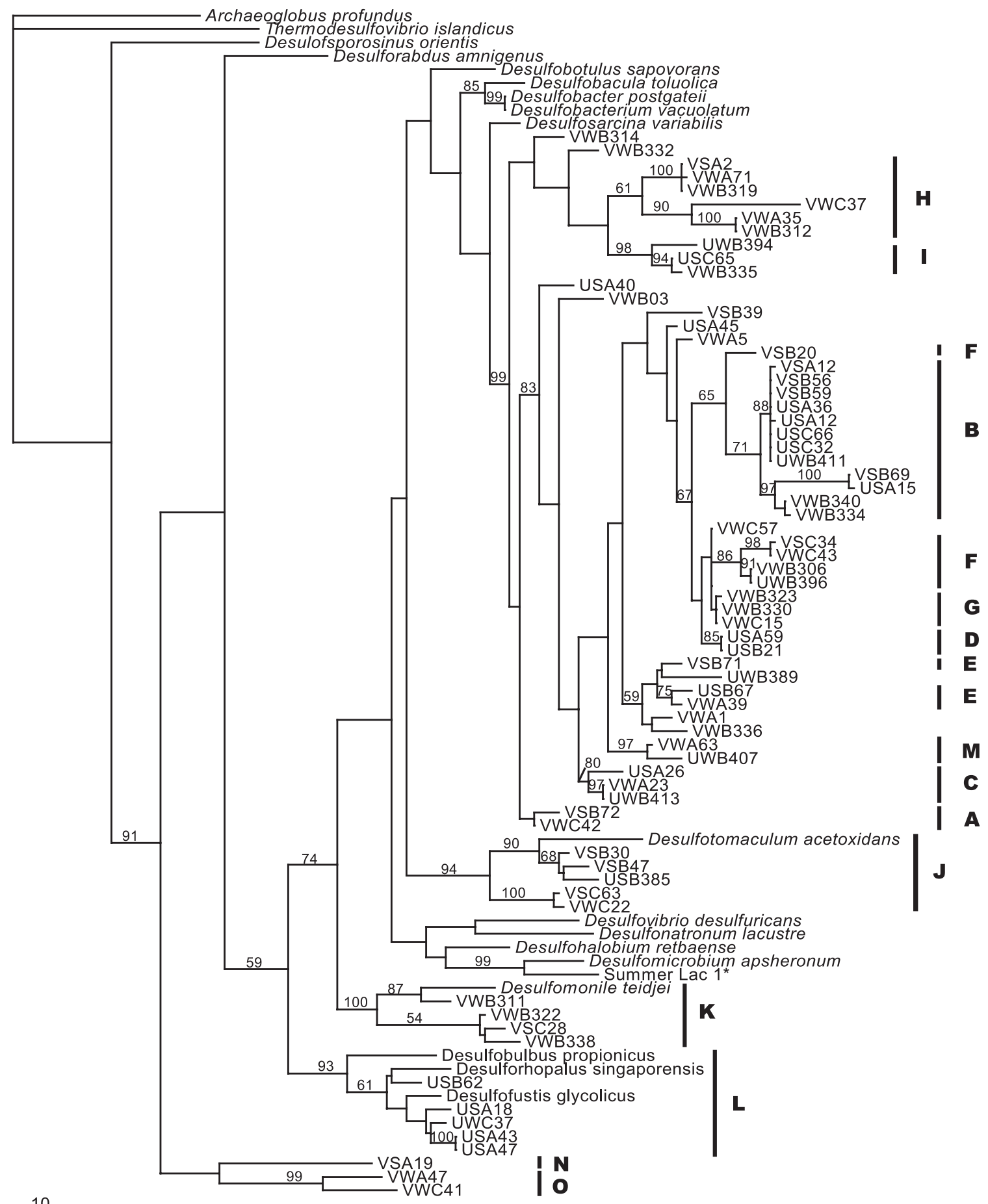

Fig. 5. Parsimony tree of $d s r \beta$-subunit sequences. Clone sequences are designated according to the site (vegetated [V] or unvegetated [U]), season (winter [W] or summer [S]), and depth (0 to $2 \mathrm{~cm}[\mathrm{~A}], 4$ to $6 \mathrm{~cm}[\mathrm{~B}], 8$ to $10 \mathrm{~cm}$ [C]) of collection. Scale bar represents 10 amino acid changes per 100 sequence positions. Capital letters in bold indicate clusters of clone sequences and reference organisms with bootstrap values $>70$ in at least 1 of 2 trees 
clone sequences associated with Desulfomonile teidjei (Cluster $\mathrm{K}_{i}$ Figs. 4 \& 5) were not consistent between the 2 subunit trees, they all originated from vegetated sediments. The smaller clusters $\mathrm{A}, \mathrm{G}, \mathrm{H}, \mathrm{N}$, and $\mathrm{O}$ also contained clone sequences found only in vegetated sediments. Sequences affiliated with Gram-positive organisms were mixed with some clones originating from the vegetated site and others from the unvegetated site. The remaining clusters of unknown clone sequences showed no specific association with sediment type. No statistically significant correlation was observed between phylotype grouping and season or sediment depth.

\section{DISCUSSION}

\section{Positive feedback between SRP abundance/activity and seagrass growth state}

Two main pathways have been considered by which plants supply carbon substrates for microbially mediated carbon metabolism in seagrass ecosystems. First, past studies have indicated that the above-ground components of seagrasses trap planktonic detritus settling in the water column over seagrass beds (Gacia et al. 1999, 2002). Second, the roots and rhizomes can release dissolved organic matter to the surrounding sediments (Moriarty \& Pollard 1982, Welsh et al. 1996). These mechanisms would increase the availability of carbon substrates to SRP during the active plant growth season, and thus their influence should vary between seasons (directly or indirectly proportional to rates of primary production). However, impacts of the second mechanism on SRP communities should be more specific and localized to the root zone.

Our results show that the activity and abundance of SRP were largely enhanced in the presence of seagrass roots during the active growth season, and differences in abundance/activity were more evident between sites than between seasons. The presence of seagrasses increased sulfate reduction activity by a factor of 5 during the summer and by a factor of 3 during the winter (Fig. 2). Moreover, sulfate reduction activity was enhanced primarily in the root zone (top 0 to $6 \mathrm{~cm}$ depth) of vegetated sediments, and the abundance of viable SRP was significantly higher in vegetated sediments during the summer growth season, but not during the winter. Similar to our results for the summer growth season, Küsel et al. (1999) observed that MPN counts of acetate-utilizing sulfate-reducers $\left(10^{6}\right.$ to $10^{7}$ cells g $^{-1}$ wet sediment) in the rhizosphere of Halodule wrightii were enriched by an order of magnitude in comparison to adjacent unvegetated sediments. It is recognized, however, that MPN counts reflect only the densities of those microorganisms that are cultivatable and, therefore, most likely already in culture. While this study presents new data through the use of molecular tools emphasizing a large number of unknown SRP phylotypes, the presentation of MPN counts represents an observed trend of greater SRP abundances in vegetated over unvegetated sediments.

The influence of vegetation on SRP activity and abundance was less pronounced during the winter when seagrasses are dormant or less active (Lee \& Dunton 2000). This may be explained by the fact that Santa Rosa Sound, near Pensacola, Florida, is a subtropical estuary exposed to mild temperatures during the winter $\left(15\right.$ to $17^{\circ} \mathrm{C}$ in this study). Thus, a lowered level of organic matter release from seagrass productivity could still be fueling microbial communities during the winter, and less seasonal change would be expected under subtropical conditions in comparison to past seasonal studies of SRP activity in temperate locations (Hines et al. 1989, 1999, Rooney-Varga et al. 1997). While it is also possible that detritus from summer vegetation and benthic algae could have helped continue fueling microbial activities throughout the winter, our plant biomass data support the abovestated conclusion that SRR are controlled by seagrass activities.

Collectively, these data suggest that the growth and carbon metabolism of SRP communities is stimulated by increased photosynthetic activity in seagrass stems and leaves (as indicated by above-ground biomass), which thereby increases the quantity of dissolved organic matter released to the rhizosphere sediments. The observed highly significant, positive correlation between depth-integrated sulfate reduction activity and above-ground biomass supports this conclusion. However, this correlation could also indicate that a covariate, such as temperature or nutrients, is regulating the functioning of the seagrasses and the microbes simultaneously. In support of our conclusions, Holmer \& Nielsen (1997) reported a similar positive linear correlation between sedimentary sulfate reduction and shoot density in a temperate seagrass bed from Denmark.

The significance of dissolved organic carbon substrates released from living roots of aquatic plants to SRP communities remains controversial and requires further study (Alongi 1998). However, past studies of marine plants have shown that the release of small molecular weight carbon compounds by roots is proportional to primary production as indicated by aboveground biomass (Lytle \& Hull 1980). Our results, together with the established importance of SRP to nitrogen fixation in the seagrass rhizosphere (Welsh 2000), further support the hypothesis of a mutualistic or symbiotic association between seagrasses and SRP 
communities in seagrass bed sediments based on the mutual exchange of fixed carbon and nitrogen (Welsh 2000).

A highly statistically significant and unprecedented negative correlation was observed in this study between sulfate reduction activity and below-ground plant biomass (Fig. 3). Below-ground plant biomass has not received the same attention in seagrass beds compared to other coastal marine, vegetated ecosystems such as the saltmarsh (Gallagher \& Plumley 1979, Alongi 1998). Thus, further study is needed to confirm the nature of this relationship. However, other marine plants such as Spartina alterniflora in saltmarshes have been shown to store or translocate organic matter in the form of roots and rhizomes during the winter dormant season (Gallagher \& Plumley 1979). The storage of below-ground biomass in winter months acts as an underground reserve for the production of above-ground shoots and leaves during the spring. We suggest that the negative correlation observed between sulfate reduction activity and below-ground plant biomass in seagrass bed sediments does not represent a direct coupling between SRP and plants. Rather, the negative correlation results from a combination of plant (organic matter translocation) and SRP (decreased carbon metabolism) physiological responses to winter conditions that are not necessarily directly related.

Porewater and solid phase geochemical measurements support our conclusions that SRP activity is coupled to seagrass growth state. Concentrations of microbial respiration products $\left(\mathrm{CO}_{2}, \mathrm{NH}_{4}^{+}\right)$were elevated in seagrass beds in comparison to unvegetated sediments at all sampling dates. SRR indicated that SRP activity was always highest in the seagrass beds compared to unvegetated sediments, and seasonally displayed the highest rates during summer. In addition, we further noted that $\mathrm{SO}_{4}{ }^{2-}$ concentrations were depleted during summer months and products of sulfate respiration (solid phase reduced S compounds; AVS + CRS $=$ TRS; data not shown) were observed at elevated concentrations at the vegetated site.

Observed $\mathrm{NO}_{3}^{-}$and $\mathrm{NH}_{4}{ }^{+}$concentrations were indicative of an active $\mathrm{N}$ cycle in the root zone of seagrass bed sediments (Fig. 1a,c). Mid-depth maxima in $\mathrm{NH}_{4}{ }^{+}$concentrations likely resulted from enhanced organic matter decomposition in the root zone of vegetated sediments. Higher $\mathrm{NO}_{3}{ }^{-}$concentrations during summer may result from enhanced nitrification.

\section{Phylogenetic analysis of SRP communities in seagrass bed sediments}

The community composition of plant-associated microorganisms would be expected to vary according to the substrates (carbon, nutrient sources) exchanged between plants and microbes. The dominant source of organic matter fueling microbial activity in seagrass beds remains uncertain and it may vary according to the latitude at which the seagrass bed is found. Boschker et al. (2000) used stable isotopes to show that benthic, pelagic, and epiphytic algae provide the main sources of carbon for microbial communities in seagrass beds growing in temperate, estuarine environments. However, stable isotope evidence provided by Holmer et al. (2001) indicated that plant below-ground biomass is responsible for delivering carbon substrates to seagrass bed microbial communities in tropical, oligotrophic systems. The present study was conducted in a subtropical estuary. The sediment microbial communities we examined may be characteristic of those found in both tropical and temperate seagrass bed sediments, i.e. they may utilize carbon from both root exudates and benthic algae. The combination of available carbon sources may explain why some SRP groups appeared to have specific associations with either vegetated or unvegetated sediments, while other groups were ubiquitous. Several phylotypes in this study (Clusters A to I, Figs. 4 \& 5) had high sequence identity ( 87 to $99 \%$ ) to sequences retrieved from unvegetated, subtidal sediments of a Danish estuary (Joulian et al. 2001, Thomsen et al. 2001).

Comparisons of $d s r$ gene sequences have not been conducted previously in seagrass beds. Past studies of 16S rRNA gene sequences conducted in seagrass bed sediments (Cifuentes et al. 2000) and the saltmarsh (Rooney-Varga et al. 1997, Hines et al. 1999, King et al. 2001) showed that SRP communities in vegetated, marine sediments are predominated by members of the Desulfobacteriaceae. This observation likely reflects similarity in the microbial communities catalyzing the terminal decomposition of organic matter in saltmarsh and seagrass bed sediments. However, we observed only a few DSR sequences specifically related to Desulfobacteriaceae. According to amino acid sequence similarity scores to known taxa, it is most likely that the sequences recovered represent new families and genera.

Two sequences from the vegetated site were found to be $\sim 94$ and $\sim 90 \%$ identical to the sequence of Desulfosarcina variabilis, a member of the Desulfobacteriaceae family. $D$. variabilis has been reported in other studies as a prevalent member of SRP communities in coastal marine sediments (Rooney-Varga et al. 1997, Sahm et al. 1999, Ravenschlag et al. 2000, Joulian et al. 2001), including saltmarsh sediments (Rooney-Varga et al. 1997, Hines et al. 1999). Members of the genus Desulfosarcina completely oxidize acetate to $\mathrm{CO}_{2}$ and are also capable of utilizing a wide variety of other electron donors (benzoate, ethanol, lactate, formate, 
$\mathrm{H}_{2}$ ). In vegetated sediments, high concentrations of a variety of carbon substrates may become available during organic matter decomposition, providing Desulfosarcina spp. with a competitive advantage over other less metabolically versatile genera.

A few of the DSR sequence clusters in the current study indicated that certain SRP groups (most of the Gram-positives and others; Clusters J, O, and Ki Figs. 4 \& 5) in seagrass beds were associated with vegetation, while others (Desulfobulbaceae; Cluster L; Figs. 4 \& 5) were primarily associated with unvegetated sediments. Küsel et al. (1999) also detected Gram-positive SRP in the root zone of seagrass bed sediments. In sediments of a freshwater wetland impacted by eutrophication, Castro et al. (2002) observed a large diversity of cloned DSR sequences. The majority of the sequences retrieved by Castro et al. (2002) were associated with Gram-positive, spore-forming Desulfotomaculum spp.

We observed inconsistencies in the phylogeny between the $\alpha$ - and $\beta$-subunit trees. The 2 clone sequences in Cluster A, VWC42 and VSB72, grouped tightly with Desulfosarcina variabilis in the $\alpha$-subunit tree (Fig. 4), while those same clone sequences in the $\beta$-subunit tree grouped alone. Similar discrepancies were also observed in Cluster $\mathrm{K}$, and some of the smaller groupings of clone sequences. This is possibly due to the occurrence of lateral gene transfer (LGT) of the $d s r$ gene, where one subunit was transferred between organisms, but the other was not (Klein et al. 2001, Friedrich 2002, Dhillon et al. 2003). However, the high diversity observed among DSR clone sequences prevented the development of primers for sequencing the complimentary DNA strand for such a large number of clone sequences, and it is likely that sequence analysis based on a single strand of DNA would promote even higher diversity due to uncertainties regarding the sequence.

A few past studies have used $d s r$ sequence comparisons to elucidate SRP community composition at higher resolution in marine sediments. Thomsen et al. (2001) found that DSR sequences retrieved at depth near the sulfate-methane transition zone $(165.5 \mathrm{~cm}$ depth) of estuarine sediments were unrelated to previously described DSR sequences, while those retrieved from surface sediments $(21.5 \mathrm{~cm})$ were closely related to members of the known genera Desulfonema, Desulfococcus, and Desulfosarcina. Desulfosarcina sequences were shown to be enriched in methane seep sediments, where SRR and methane concentrations are high (Orphan et al. 2001). Also, Liu et al. (2003) recently observed extensive SRP diversity in continental margin sediment and showed that SRP community structure was dependent on sediment depth and carbon availability. Our results concur with previous work in that the majority of our clone sequences were not closely related to previously described $d s r$ gene sequences. However, our results showed no trend of SRP distribution according to sediment depth, although we examined a much narrower depth range in comparison to Thomsen et al. (2001). Further, since our study occurred in shallow coastal sediments, SRP were not likely to be limited by carbon availability, even at the unvegetated site.

Acknowledgements. We are grateful to the US Environmental Protection Agency for the use of their boats and facilities at the NHEERL Gulf Ecology Division, Gulf Breeze, Florida, USA. This study was partially supported by the Naval Research Laboratory, Stennis, Mississippi, USA. Also, many thanks go to Dr. D. Balkwill for help with sequence analysis, and D. Dalton, H. Skelton, H. Adams, D. Westbrook, Drs. S. and M. Dollhopf, S. O'Brien, R. Seston, and Captain J. Patrick for help with collecting and processing of samples.

\section{LITERATURE CITED}

Alongi DM (1998) Mangroves and salt marshes. In: Coastal ecosystem processes. CRC Press, Boca Raton, FL, p 43-93

American Public Health Association (1969) Standard methods for the examination of water and wastewater, including bottom sediments and sludge. American Public Health Association, Washington, DC, p 604-609

Bagwell CE, La Rocque JR, Smith GW, Polson SW, Friez MJ, Longshore JW, Lovell CR (2002) Molecular diversity of diazotrophs in oligotrophic tropical seagrass bed communities. FEMS Microbiol Ecol 39:113-119

Boschker HTS, Wielemaker A, Schaub BEM, Holmer M (2000) Limited coupling of macrophyte production and bacterial carbon cycling in the sediments of Zostera spp. meadows. Mar Ecol Prog Ser 203:181-189

Braman RS, Hendrix SA (1989) Nanogram nitrate and nitrate determination in environmental and biological materials by vanadium(III) reduction with chemiluminescence detection. Analyt Chem 61:2715-2718

Capone DG (1982) Nitrogen fixation (acetylene reduction) by rhizosphere sediments of the eelgrass Zostera marina. Mar Ecol Prog Ser 10:67-75

Capone DG (1988) Benthic nitrogen fixation. In: Blackburn TH, Sørensen J (eds) Nitrogen cycling in coastal marine sediments. John Wiley, Chichester, p 85-123

Capone DG, Taylor BF (1980) Nitrogen fixation in the rhizosphere of Thalassia testudinum. Can J Microbiol 26: 998-1005

Castro HF, William NH, Ogram A (2000) Phylogeny of sulfatereducing bacteria. FEMS Microbiol Ecol 31:1-9

Castro HF, Reddy KR, Ogram A (2002) Composition and function of sulfate-reducing prokaryotes in eutrophic and pristine areas of the Everglades. Appl Environ Microbiol 68: $6129-6137$

Cifuentes A Anton J, Benlloch S, Donnelly A, Herbert RA, Rodriguez-Vakra F (2000) Prokaryotic diversity in Zostera noltii-colonized marine sediments. Appl Environ Microbiol 66:1715-1719

Cord-Ruwsich (1985) A quick method for the determination of dissolved and precipitated sulfides in cultures of sulfatereducing bacteria. J Microbiol Methods 4:33-36

Devereux R, Stahl DA (1993) Phylogeny of sulfate-reducing bacteria and a perspective for analyzing their natural 
communities. In: Odom JM, Singleton R (eds) The sulfatereducing bacteria: contemporary perspectives. SpringerVerlag, Berlin, p 131-160

Devereux R, Delaney M, Widdel F, Stahl DA (1989) Natural relationships among sulfate-reducing eubacteria. J Bacteriol 171:6689-6695

Devereux R, He S, Doyle CL, Orkland S, Stahl DA, LeGall J, Whitman WB (1990) Diversity and origin of Desulfovibrio species: phylogenetic definition of a family. J Bacteriol 172:3609-3619

Dhillon A, Tesek A, Dillon J, Stahl DA, Sogin ML (2003) Molecular characterization of sulfate-reducing bacteria in the Guaymas Basin. Appl Environ Microbiol 69:2765-2772

Duarte CM, Chiscano CL (1999) Seagrass biomass and production: a reassessment. Aquat Bot 65:159-174

Edgcomb VP, McDonald JH, Devereux R, Smith DW (1999) Estimation of bacterial cell numbers in humic acid-rich salt marsh sediments with probes directed to $16 \mathrm{~S}$ ribosomal DNA. Appl Environ Microbiol 65:1516-1523

Fossing H, Jørgensen BB (1989) Measurement of bacterial sulfate reduction in sediments: evaluation of a single-step chromium method. Biogeochemistry 8:223-237

Friedrich MW (2002) Phylogenetic analysis reveals multiple lateral transfers of adenosine-5' -phosphosulfate reductase genes among sulfate-reducing microorganisms. J Bacteriol 184:278-289

Frischer ME, Danforth JM, Newton Healy MA, Saunders FM (2000) Whole-cell versus total RNA extraction for analysis of microbial community structure with 16S rRNA-targeted oligonucleotide probes in salt marsh sediments. Appl Environ Microbiol 66:3037-3043

Gacia E, Granata TC, Duarte CM (1999) An approach to the measurement of particle flux and sediment retention within seagrass (P. oceanica) meadows. Aquat Bot 65: 255-268

Gacia E, Duarte CM, Middelburg JJ (2002) Carbon and nutrient deposition in a Mediterranean seagrass (Posidonia oceanica) meadow. Limnol Oceanogr 47:23-32

Gallagher JL, Plumley FG (1979) Underground biomass profiles and productivity in Atlantic Coastal Marshes. Am J Bot 66:156-161

Hall PO, Aller RC (1992) Rapid, small-volume, flow injection analysis for $\mathrm{CO}_{2}$ and $\mathrm{NH}_{4}{ }^{+}$in marine and freshwaters. Limnol Oceanogr 37:1113-1119

Hansen JW and others (2000) Effect of the seagrass Zostera capricorni on sediment microbial processes. Mar Ecol Prog Ser 199:83-96

Hines ME, Knollmeyer SL, Tugel JB (1989) Sulfate reduction and other sedimentary biogeochemistry in a northern New England salt marsh. Limnol Oceanogr 34:578-590

Hines ME, Evans RS, Sharak Genthner BR, Willis SG, Friedman S, Rooney-Varga JN, Devereux R (1999) Molecular phylogenetic and biogeochemical studies of sulfatereducing bacteria in the rhizosphere of Spartina alterniflora. Appl Environ Microbiol 65:2209-2216

Holmer M, Bondgaard EJ (1991) Photosynthetic and growth response of eelgrass to low oxygen and high sulfide concentrations during hypoxic events. Aquat Bot 70:29-38

Holmer M, Nielsen SL (1997) Sediment sulfur dynamics related to biomass-density patterns in Zostera marina (eelgrass) beds. Mar Ecol Prog Ser 146:163-171

Holmer M, Andersen FO, Nielsen SL, Boschker HT (2001) The importance of mineralization based on sulfate reduction for nutrient regeneration in tropical seagrass sediments. Aquat Bot 71:1-17

Jørgensen BB (1978) A comparison of methods for quantification of bacterial sulfate reduction in coastal marine sedi- ment: I. Measurements with radiotracer technique. Geomicrobiol J 1:11-27

Jørgensen BB (2000) Bacteria and marine biogeochemistry. In: Schultz HD, Zabel M (eds) Marine geochemistry. Springer, Berlin, p 173-207

Joulian C, Ramsing NB, Ingvorsen K (2001) Congruent phylogenies of most common small-subunit rRNA and dissimilatory sulfite reductase gene sequences retrieved from estuarine sediments. Appl Environ Microbiol 67:3314-3318

King JK, Kostka JE, Frischer ME, Saunders FM, Jahnke RA (2001) A quantitative relationship that demonstrates mercury methylation rates in marine sediments are based on the community composition and activity of sulfate-reducing bacteria. Environ Sci Technol 35:2491-2496

Klein M, Friedrich M, Roger AJ, Hugenholtz P and 5 others (2001) Multiple lateral transfers of dissimilatory sulfite reductase genes between major lineages of sulfate-reducing prokaryotes. J Bacteriol 183:6028-6035

Klumpp DW, Howard RK, Pollard DA (1989) Trophodynamics and nutritional ecology of seagrass communities. In: Larkum AWD, McComb AJ, Sherherd SA (eds) The biology of seagrasses: a treatise on the biology of seagrasses with special reference to the Australian region. Elsevier, New York, p 394-457

Knoblauch C, Jørgensen BB, Harder J (1999) Community size and metabolic rates of psychrophilic sulfate-reducing bacteria in arctic marine sediments. Appl Environ Microbiol 65:4230-4233

Küsel K, Pinkart HC, Drake H, Devereux R (1999) Acetogenic and sulfate-reducing bacteria inhabiting the rhizosphere and deep cortex cells of the seagrass Halodule wrightii. Appl Environ Microbiol 65:5117-5123

Lee KS, Dunton KH (2000) Diurnal changes in pore water sulfide concentrations in the seagrass Thalassia testudinum beds: the effects of seagrasses on sulfide dynamics. J Exp Mar Biol Ecol 255:201-214

Li L, Kato C, Horikoshi K (1999) Microbial diversity in sediments collected from the deepest cold-seep area, the Japan Trench. Mar Biotechnol 1:391-400

Liu X, Bagwell CE, Wu L, Devol AH, Zhou J (2003) Molecular diversity of sulfate-reducing bacteria from two different continental margin habitats. Appl Environ Microbiol 69: 6073-6081

Llobet-Brossa E, Rabus R, Böttcher ME, Könnecke M and 6 others (2002) Community structure and activity of sulfatereducing bacteria in an intertidal surface sediment: a multi-method approach. Aquat Microb Ecol 29:211-226

Lustwerk RL, Burdige DJ (1995) Elimination of dissolved sulfide interference in the flow injection determination of $\mathrm{SCO}_{2}$ by addition of molybdate. Limnol Oceanogr 40: 1001-1012

Lytle RW Jr, Hull RJ (1980) Annual carbohydrate variation in culms and rhizomes of smooth cordgrass (Spartina alterniflora Loisel). Agronomy J 72:942-946

Moriarty DJW, Pollard PC (1982) Diel variation of bacterial productivity in seagrass (Zostera capricorni) beds measured by rate of thymidine incorporation into DNA. Mar Biol 72:165-173

Nielsen LB, Finster K, Welsh DT, Donelly A, Herbert RA, de Wit R, Lomstein BA (2001) Sulphate reduction and nitrogen fixation rates associated with roots, rhizomes and sediments from Zostera noltii and Spartina maritima meadows. Environ Microbiol 3:63-71

Orphan VJ, Hinrichs KU, Ussler W II, Paul CK, Taylor LT, Sylva SP, Hayes JM, Delong EF (2001) Comparative analysis of methane-oxidizing archaea and sulfatereducing bacteria in anoxic marine sediments. Appl Envi- 
ron Microbiol 67:1922-1934

Pérez-Jiménez JR, Young LY, Kerkhof LJ (2001) Molecular characterization of sulfate-reducing bacteria in anaerobic hydrocarbon-degrading consortia and pure cultures using dissimilatory sulfite reductase $(d s r A B)$ genes. FEMS Microbiol Ecol 1212:1-6

Ravenschlag K, Sahm K, Knoblauch C, Jørgensen BB, Amann R (2000) Community structure, cellular rRNA content, and activity of sulfate-reducing bacteria in marine arctic sediments. Appl Environ Microbiol 66:3592-3602

Rooney-Varga JN, Devereux R, Evans RS, Hines ME (1997) Seasonal changes in the relative abundance of uncultivated sulfate-reducing bacteria in a salt marsh sediment and in the rhizosphere of Spartina alterniflora. Appl Environ Microbiol 63:3895-3901

Rooney-Varga JN, Genther BR, Devereux R, Willis SG, Friedman SD, Hines ME (1998) Phylogenetic and physiological diversity of sulphate-reducing bacteria isolated from a salt marsh sediment. Syst Appl Microbiol 21:557-568

Sahm K, MacGregor BJ, Jørgensen BB, Stahl DA (1999) Sulfate reduction and vertical distribution of sulphatereducing bacteria quantified by rRNA slot-blot hybridization in a coastal marine sediment. Environ Microbiol 1: $65-74$

Short FT (1987) Effects of sediment nutrients on seagrasses: literature review and mesocosm experiment. Aquat Bot 27:41-57

Terrados J, Duarte CM (2000) Experimental evidence of

Editorial responsibility: Dittmar Hahn,

San Marcos, Texas, USA reduced particle suspension within a seagrass (Posidonia oceanica L.) meadow. J Exp Mar Biol Ecol 243:45-53

Thomsen TR, Finster K, Ramsing NB (2001) Biogeochemical and molecular signatures of anaerobic methane oxidation in a marine sediment. Appl Environ Microbiol 67: 1646-1656

Wagner M, Roger AJ, Flax JL, Brusseau GA, Stahl DA (1998) Phylogeny of dissimilatory sulfite reductases supports an early origin of sulfate respiration. J Bacteriol 180: 2975-2982

Waisel Y, Agami M (1996) Ecophysiology of roots of submerged aquative plants, 2nd edn. In: Waisel Y, Eshel A, Kafkafi U (eds) Plant roots: the hidden half. Marcel Dekker, Washington, DC, p 895-909

Welsh DT (2000) Nitrogen fixation in seagrass meadows: regulation, plant-bacteria interactions and significance to primary productivity. Ecol Lett 3:58-71

Welsh DT, Wellsbury P, Borgues S, de Wit R, Herbert RA (1996) Relationship between porewater organic carbon content, sulphate reduction and nitrogen fixation (acetylene reduction) in the rhizosphere of Zostera noltii. Hydrobiologia 329:175-183

Widdel F, Bak F (1992) Gram-negative mesophilic sulfatereducing bacteria. In: Balows A, Truper HG, Dworkin M, Harder W, Schleifer KH (eds) The prokaryotes: a handbook of the biology of bacteria: ecophysiology, isolation, identification, applications. Springer-Verlag, New York, p 3352-3378

Submitted: June 14, 2004; Accepted: September 3, 2004 Proofs received from author(s): October 29, 2004 